\title{
RANCANG BANGUN DAN PENGUJIAN ALAT PENGADUK DODOL
}

\author{
Mustofa $^{1)}$, Sjahril Botutihe ${ }^{2)}$ \\ 1) Tim Pengajar pada Program Studi Mesin dan Peralatan Pertanian, Politeknik Gorontalo \\ ${ }^{2}$ Tim Pengajar pada Program Studi Mesin dan Peralatan Pertanian, Politeknik Gorontalo
}

\begin{abstract}
ABSTRAK
Penelitian ini merupakan penelitian yang didasarkan pada teknologi tepat guna yang diharapkan dapat menjadi salah satu solusi dalam peningkatan kualitas dan kuantitas produk-produk makan ringan, khususnya dodol. Dalam penelitian ini dirancang sebuah alat/mesin pengaduk yang digerakkan dengan motor penggerak. Besarnya daya yang digunakan untuk menggerakkan pengaduk merupakan variabel tetap, termasuk juga putaran pengadukan. Sementara api yang digunakan untuk memasak dodol berasal dari gas LPG. Penelitian ini juga merupakan sebagai awal untuk penelitian selanjutnya tentang pengembangan alat pengaduk dodol. Fokus kajian dalam penelitian membandingkan produk dodol yang dihasilkan dari alat dalam penelitian ini dengan yang dihasilkan secara tradisional. Inidikator perbandingan yang menjadi kajian adalah waktu yang diperlukan selama pemasakan dodol dan kualitas dodol yang dihasilkan meliputi tekstur, rasa dan aroma. Berdasarkan hasil penelitian diperoleh bahwa pemebuatan dodol menggunakan mesin memerlukan waktu selama 101 menit, yakni 38 menit lebih cepat dibandingkan secara tradisional. Selain itu, kualitas dodol yang dihasilkan menggunakan mesin memiliki tekstur yang kenyal, lebih coklat dan memiliki aroma dan rasa yang tinggi.
\end{abstract}

Kata kunci : Dodol, Teknologi Tepat Guna, Alat Pengaduk Dodol

\section{BUILDING DESIGN AND TESTING OF DODOL GRINDING TOOLS}

\begin{abstract}
This research is a research based on appropriate technology that is expected to be one of the solutions in improving the quality and quantity of light meal products, especially dodol. In this study a device / stirrer is designed, which is driven by a motor drive. The amount of power used to drive the stirrer is a fixed variable, including the stirring cycle. While the fire used for cooking dodol comes from LPG gas. This research is also the beginning of further research on the development of dodol stirrers. The focus of the study in the study compared dodol products produced from the tools in this study with those produced traditionally. The comparison indicator that becomes the study is the time needed during cooking dodol and the quality of dodol produced includes texture, taste and aroma. Based on the results of the study, it was found that making dodol using a machine takes 101 minutes, which is 38 minutes faster than traditionally. In addition, the quality of dodol produced using a machine has a chewy texture, is more brown and has a high aroma and taste.
\end{abstract}

Key words : Dodol, Appropriate Technology, Dodol Stirrer 


\section{PENDAHULUAN}

\section{Latar Belakang}

Dodol merupakan salah satu jenis makanan yang sering digemari oleh masyarakat Indonesia di berbagai daerah. Makanan ini terkadang memiliki perbedaan di setiap daerah. Sebagai contoh, masyarakat Jawa umumnya menyebutnya sebagai jenang yang sering dibuat hanya pada acara-acara tertentu seperti khitanan atau acara pernikahan. Di beberapa daerah, dodol memiliki cita rasa yang berbeda-beda tergantung pada bahan dasar yang digunakan. Walaupun demikian, proses pembuatannya tidak jauh berbeda. Artinya, prinsip yang digunakan dalam membuat dodol sama. Dodol banyak diminati masyarakat karena disamping rasanya yang enak, bahan dasar pembuatannya pun sangat tersedia. Oleh karena itu, tidak mengherankan jika mayoritas masyarakat Indonesia tidak asing lagi dengan makan jenis ini.

Secara umum, untuk keperluan komersil dodol biasanya diproduksi oleh kelompok usaha tingkat bawah hingga menengah. Hal ini didasarkan pada produksinya masih dalam skala yang kecil hingga skala menengah. Keterbatasan ini salah satu faktornya adalah tenaga yang dibutuhkan dalam memproduksi dodol itu sendiri. Mayoritas dodol diproduksi dengan bantuan tenaga manusia yang proses pengadukannya secara manual. Proses ini tentunya memiliki beberapa kelemahan yang menjadi masalah dalam membuat dodol itu sendiri. Misalnya, keterbatasan tenaga manusia yang digunakan untuk proses pengadukan. Artinya, pada kondisi tertentu proses pengadukan tidak sama sehingga berdampak pada tidak meratanya tingkat kematangan dodol. Pada bagian tertentu sudah matang, bahkan hangus, namun pada bagian yang lain masih mentah. Hal ini akan mempengaruhi kualitas produk dodol yang dihasilkan seperti teksturnya, aroma, juga rasanya pun berbeda. Selain itu, penggunaan tenaga manusia juga membutuhkan waktu yang cukup lama dan relatif berbeda-beda. Salah satu faktornya adalah tingkat pengapian yang tidak merata dan tetap karena kebanyakan masih menggunakan kayu sebagai bahan bakar. Sehingga api yang digunakan untuk memasak dodol sulit dikontrol. Akhirnya mempengaruhi kualitas dan tingkat kematangan dodol.

Untuk mengatasi berbagai masalah di atas, diperlukan adanya alat/mesin yang dapat menjadi alternatif untuk membuat dodol. Alat/mesin ini diharapkan mampu menggantikan peran manusia dalam pengadukan saat membuat dodol. Dengan demikian, alat/mesin tersebut dapat menunjang produksi dodol yang berkualitas, baik dari segi kematangan, aroma, dan cita rasa.

\section{TINJAUAN PUSTAKA}

\section{Pengertian Dodol}

Dodol merupakan salah satu jenis makanan tradisional yang sudah dikenal masyarakat. Dodol dalam bahasa Inggris dikenal dengan sebutan Sweet Pastry yang merupakan makanan khas Indonesia yang memiliki tekstur plastis (Krisnakai, 2017). Menurut SNI 01-2986-1992, dodol adalah sejenis makanan yang terbuat dari tepung beras ketan, santan kelapa dan gula dengan atau tanpa penambahan bahan lainnya yang diizinkan.

Dodol merupakan salah satu jenis produk olahan hasil pertanian yang bersifat semi basah, berwarna putih sampai cokelat, dibuat dari campuran tepung ketan, gula, dan santan. Pengolahan dodol sudah dikenal masyarakat, prosesnya sederhana, murah dan banyak menyerap tenaga kerja (Soemaatmadja, 1997). Berdasarkan pengertian tersebut diketahui bahwa komponen utama dalam pembuatan dodol adalah tepung beras ketan, santan kelapa, dan gula. Bahan lain juga dapat ditambahkan selama tidak mengurangi mutu dodol, apalagi membahayakan jika dikonsumsi.

Jenis-jenis Dodol

Dodol dapat dikelompokkan dalam berbagi jenis, salah satunya adalah jenis dodol yang didasarkan pada daerah asal dodol dibuat, diantaranya:
a. Dodol Garut
b. Dodol Betawi
c. Dodol Kandangan
d. Dodol susu

Beberapa contoh dodol yang lain yaitu dodol yang terbuat dari bahan tambahan berupa buahbuahan seperti dodol durian, dodol sirsak, dodol Apel Malang, dodol nangka, dodol jahe, dodol labu kuning, dan lain-lain.

\section{Proses Pembuatan Dodol}

Secara umum, proses pembuatan dodol dilakukan secara tradisional, baik untuk keperluan komersil atau untuk acara-acara tertentu. Proses pembuatan dodol yang demikian tentu memiliki kelemahan, diantaranya adalah kurang memperhatikan faktor-faktor yang mempengaruhi kualitas dodol, menggunakan tenaga manusia, memerlukan waktu yang cukup lama, serta pengapian yang sulit dikontrol. Akibatnya dodol yang dihasilkan memiliki tekstur yang tidak kalis, aromanya kurang sedap, atau bahkan kematangannya pun tidak merata/homogen. 
Pembuatan dodol dapat dilakukan melalui beberapa tahapan, yaitu:

a. Persiapan yang meliputi persiapan alat, pemilihan bahan, dan penimbangan bahanbahan yang digunakan.

b. Pelaksanaan yang dilakukan dalam beberapa tahapan berikut:

- Mencairkan gula merah, gula pasir dengan menambahkan santan kental

- Mencampurkan gula yang telah dicairkan dengan tepung beras ketan

- Proses pemasakan

- Pendinginan dan pencetakan

c. Penyelesaian yang mencakup pembungkusan dan pengemasan.

\section{Kualitas Dodol}

Kualitas dodol dapat dipengaruhi oleh beberapa faktor, antara lain:

\section{a. Bahan baku}

Secara umum, bahan utama dodol adalah tepung dan santan. Kedua bahan utama ini tentunya harus memiliki kriteria sebagai standar mutu dalam pembuatan dodol. Jika tidak, maka dodol yang dihasilkan kuran baik. Diantara ciri-ciri dodol yang kurang baik adalah warna yang kurang cokelat, tekstur yang kurang kalis, dan rasanya yang tidak manis. Tepung yang digunakan biasanya tepung beras ketan. Tepung beras ketan dikatan baik apabila tidak bau apek atau adanya kutu. Sementara santan yang digunakan adalah santan kental dan cair dari kelapa yang masih baru serta tidak terlalu tua. Disamping bahan dasar, bahan-bahan lain juga dapat ditambahkan sebagai salah satu faktor untuk keperluan cita rasa yang berbeda. Bahan-bahan tersebut umumnya berupa buahbuahan seperti pisang, durian bahkan labu kuning juga menjadi salah satu bahan tambahan dalam pembuatan dodol.

b. Proses pembuatan

Proses pembuatan memiliki peran dalam menentukan kualitas dodol disamping bahan baku yang digunakan. Hal ini karena proses pembuatan dodol erat kaitannya dengan produk/hasil yang akan diperoleh meliputi tekstur, aroma, dan cita rasa. Dalam pembuatan dodol, homogenitas campuran juga perlu diperhatikan, sebab homogenitas akan berperan dalam tingkat kematangan dodol dan kekompakkan, serta tekstur yang halus.

c. Pengemasan

Pengemasan adalah suatu proses pembungkusan, pewadahan atau pengepakan suatu produk dengan menggunakan bahan tertentu sehingga produk yang ada di dalamnya bisa tertampung dan terlindungi. Pengemasan dodol yang tidak tertutup rapat akan mempermudah terjadinya kontaminasi, sehingga dodol yang dihasilkan akan lebih cepat basi, berjamur dan tengik.

Menurut SNI 01-2986-1992 disebutkan bahwa dodol yang bermutu harus memenuhi beberapa persyaratan sebagaimana disajikan pada Tabel 1.

Tabel 1. Syarat Mutu Dodol

\begin{tabular}{|c|c|c|}
\hline $\mathrm{No}$ & Uraian & Persyaratan \\
\hline 1 & $\begin{array}{l}\text { Keadaan (aroma, rasa, } \\
\text { dan warna) }\end{array}$ & Normal \\
\hline 2 & Air & Maksimal 20\% \\
\hline 3 & $\mathrm{Abu}$ & Maksimal 1,5\% \\
\hline 4 & $\begin{array}{l}\text { Gula dihitung sebagai } \\
\text { sakarosa }\end{array}$ & Minimal 40\% \\
\hline 5 & Protein & Minimal 3\% \\
\hline 6 & Lemak & Minimal 7\% \\
\hline 7 & Serat kasar & Maksimal 1,0\% \\
\hline 8 & Pemanis buatan & Tidak boleh ada \\
\hline 9 & $\begin{array}{l}\text { Logam-logam berbahaya } \\
(\mathrm{PB}, \mathrm{Cu}, \mathrm{Hg})\end{array}$ & Tidak ternyata \\
\hline 10 & Arsen & Tidak ternyata \\
\hline 11 & Kapang & Tidak boleh ada \\
\hline
\end{tabular}

Alat Pengaduk Dodol

Alat Tradisional

Masyarakat secara umum, biasanya menggunakan alat sederhana dalam membuat dodol (Gambar 1). Alat ini yang terdiri dari tungku biasa dan wajan yang digunakan sebagai wadah saat pemasakan dodol. Disamping itu, proses pengadukannya pun masih menggunakan tenaga manusia. Proses pembuatan dodol yang seperti ini tentu memiliki beberapa kekurangan seperti lamanya proses pengadukan, pekerja sering merasakan tidak nyaman (pegal-pegal, nyeri pada punggung, mudah kelelahan), dan membutuhkan tingkat konsentrasi guna menghindari kecelakaan. Akibatnya berpengaruh pada kualitas dodol yang dihasilkan.

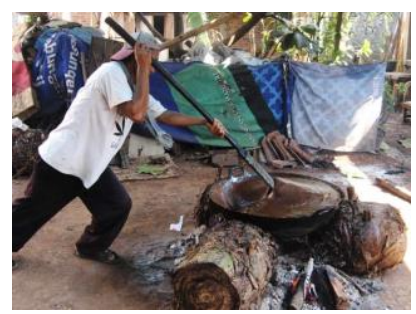

Gambar 1. Proses Pembuatan Dodol secara Tradisional (Anonim, 2013). 


\section{Alat Pengaduk Dodol Semi-otomatis}

Alat ini merupakan modifikasi dari alat tradisional, dimana proses pengadukannya tidak lagi menggunakan tenaga manusia. Akan tetapi, sumber api sebagai pembakaran untuk pemasakan dodol masih menggunakan kayu bakar yang dibakar pada tungku pembakaran (Gambar 2). Cara kerja alat ini yaitu adoanan dodol dimasukkan ke dalam kuali lalu pisau pengaduk diturunkan dan mengunci poros pisau pengaduk. Kemudian menyalakan stop kontak untuk menggerakan pulley 1 kemudian pulley akan menggerakan $\mathrm{v}-$ belt dan v-belt akan menggerakan pulley 2, pulley 2 ini tersambung dengan gearbox dan tersambung dengan roda gigi 1 kemudian roda gigi menggerakan rantai dan rantai akan menggerakan roda gigi 2 tersambung dengan poros yang akan menggerakan mata pengaduk (Riandadari, D., 2017).

\section{Alat Pengaduk Dodol Otomatis}

Semakin berkembangnya teknologi dan tuntutan masyarakat dalam meningkatkan usaha kreatif, maka alat pengaduk/pembuat dodol telah mengalami berbagai modifikasi. Hal ini dilakukan untuk mengatasi kekurangan-kekurangan alat-alat sebelumnya. Disamping itu, efektifitas kerja alat juga merupakan salah indikator dalam rangka pengembangan alat tersebut. Alhasil, telah dibuat berbagai model dan tipe alat pengaduk dodol otomatis. Salah satunya adalah modifikasi alat pengaduk dodol yang telah dilakukan oleh Riandadari (2017) sebagaimana dapat dilihat pada Gambar 3.

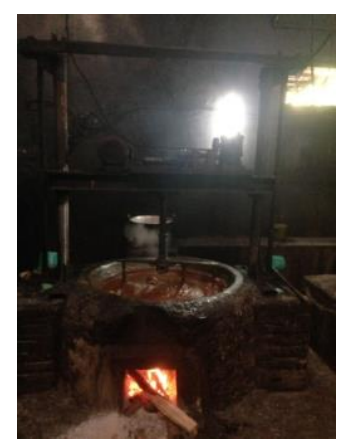

Gambar 2. Alat Pengaduk Dodol Semi-otomatis (Riandadari, D., 2017)

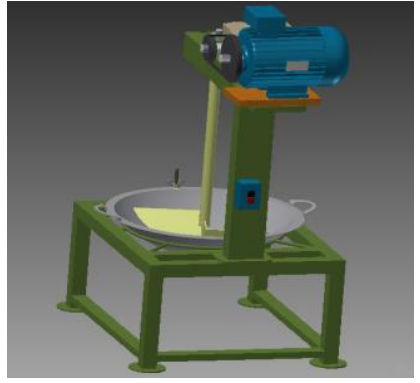

Gambar 3. Mesin Pengaduk Dodol dan Jenang Tipe Vertikal (Riandadari, D., 2017)

Mekanisme kerja alat ini adalah rumah poros pisau pengaduk diangkat dan adoanan dimasukkan ke kuali. Selanjutnya rumah poros pisau pengaduk kembali diturunkan dan saat stop kontak dinyalakan motorpun akan bergerak dan berputar menggerakkan pulley 1 kemudian pulley akan menggerakkan v-belt dan v-belt akan menggerakkan pulley 2, pulley 2 ini tersambung dengan gearbox, gearbox ke poros as digerakan menggunakan rantai yang akan menggerakkan rangka pengaduk. Rangka pengaduk ini akan bergerak memutar dan menggerakkan mata pengaduk (Riandadari, D., 2017).

Selain itu, ada juga mesin pengaduk dodol yang diproduksi oleh CV. Rumah Mesin yang memiliki kapasitas produksi 5 dan $10 \mathrm{~kg}$ (Gambar 4). Alat ini memiliki dimensi $500 \mathrm{~mm} \mathrm{x} 450 \mathrm{~mm} \mathrm{x}$ $700 \mathrm{~mm}$, terbuat dari bahan rangka plat baja. Penggerak menggunakan motor listrik AC 220 volt 1 fase yang menghasilkan daya sebesar $1 \mathrm{HP}$, menggunakan kompor Liquified Petroleum Gas $(L P G)$ sebagai pemanas bejana yang berbentuk silinder dengan sistem double jacket dan telah dipasarkan dengan harga 9 juta rupiah.

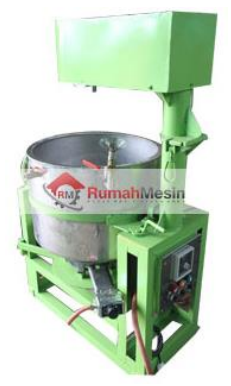

Gambar 4. Mesin Pengaduk Dodol CV. Rumah Mesin Kapasitas $5 \mathrm{Kg}$ dan (b) $10 \mathrm{Kg}$ (Rumah Mesin, 2018) 


\section{METODE PENELITIAN}

\section{Waktu dan Tempat Penelitian}

Penelitian ini dilaksanakan pada bulan

Juli-Desember 2018 di Laboratorium Mesin dan

Peralatan Pertanian Politeknik Gorontalo.

\section{Alat dan Bahan}

Alat

Alat-alat yang digunakan dalam penelitian ini diantaranya mesin las listrik, mesin las karbit, circular saw, gurinda, gergaji besi, kunci inggris, kunci pas, obeng plus, obeng minus, catok, solder, bor portable, mata bor, kompor gas, amperemeter, motor listrik 3 PK, wajan, dandang, kayu pengaduk, mistar, dan kuas.

\section{Bahan}

Bahan-bahan yang digunakan terbagi dalam dua bagian, yaitu:

a. Bahan untuk pembuatan alat pengaduk dodol antara lain besi siku ukuran $4 \times 4 \mathrm{~cm}$ tebal 4 $\mathrm{mm}$, cat, besi silinder (poros) diameter $3 \mathrm{~cm}$, batu gurinda halus, batu gurinda cutting, puli, elektroda, mur, baut, timah solder, regulator, selang regulator, pulley, bearing, selang gas LPG, selang regulator, valve, cat besi dan tiner.

b. Adapun bahan untuk pengujian alat dalam pembuatan dodol antara lain gas LPG, tepung beras dan tepung ketan, santan kelapa, gula merah, gula pasir.

Rancangan Fungsional

Berdasarkan fungsinya mesin pengaduk dodol dibagi dalam beberapa bagian utama, antara lain: a) kerangka utama, b) tempat motor, c) sistem transmisi, d) pengaduk, e) tempat LPG, dan f) wadah. Kelima bagian ini merupakan kesatuan yang dapat menjadikan alat berfungsi sehingga dalam penggunaannya mendapatkan hasil yang diharapkan.

Rancangan Struktural

a. Kerangka. Kerangka ini dimaksudkan untuk menopang motor penggerak, gaya yang terjadi saat transmisi, wadah, dan gas LPG. Sementara pengaduk ditopang/difungsikan oleh poros dalam sistem transmisi. Kerangka utama terbuat dari besi siku dengan dimensi $4 \mathrm{~cm} \mathrm{x} 4$ $\mathrm{cm} \times 0,4 \mathrm{~cm}$.

b. Motor. Motor yang digunakan adalah motor listrik sebagai sumber gerak merupakan motor dengan kekuatan 3 PK.

c. Sistem Transmisi. Sistem ini dimaksudkan untuk menghubungkan daya dari motor penggerak ke poros pengaduk. Pemindahan transmisi daya ini dilakukan dengan menggunakan ban dan roda gigi. Transmisi daya menggunakan ban dipakai pada bagian motor dengan pulley, sementara transmisi dengan ukuran pulley yang lebih besar digunakan untuk menggerakan poros pengaduk.

d. Pengaduk. Pengaduk yang digunakan memiliki dua bentuk yang sama tapi memiliki dimensi yang berbeda tergantung dimensi wadah yang digunakan. Selain itu, pengaduk dihubungkan dengan poros pengaduk dengan posisi horizontal dan vertikal. Posisi ini dimungkinkan agar seluruh bagian dalam wadah saat pengadukan dapat terjangkau sehingga proses pemasakannya pun merata.

e. Wadah. Wadah yang digunakan untuk menampung bahan-bahan dalam pembuatan dodol adalah panci/wajan yang mampu menampung bahan sebanyak $5 \mathrm{~kg}$.

f. Sumber panas. Sumber panas yang digunakan untuk memasak dodol yaitu gas LPG $5 \mathrm{~kg}$.

g. Poros Pengaduk. Poros pada umumnya berfungsi untuk memindahkan daya dan putaran. Bentuk dari poros adalah silinder baik pejal maupun berongga. Poros yang digunakan pada penelitian ini merupakan poros transmisi yang mentransmisikan daya dan putaran sehingga poros ini akan menerima momen bending/beban lentur dan momen torsion/beban puntir. Daya yang ditranmisikan kepada poros melalui kopling, roda gigi, pulley maupun dengan sprocket.

Teknik Pengumpulan dan Analisis Data

1. Pembuatan dodol dilakukan dengan dua metode, yaitu metode tradisional dan dengan menggunakan alat pengaduk dodol otomatis. Metode pertama menggunakan tenaga manusia dalam proses pengadukan dan bahan bakar kayu sebagai sumber pengapian. Metode kedua pengadukan dilakukan dengan bantuan pengaduk yang digerakkan oleh motor dan sumber pengapian adalah gas LPG.

2. Bahan-bahan yang digunakan dalam pembuatan dodol antara lain santan kelapa, tepung beras, tepung ketan, gula merah dan gula pasir.

3. Membuat adonan menjadi dua bagian. Adonan pertama merupakan campuran antara santan kental dengan gula merah serta sedikit gula pasir. Adonan keedua merupakan campuran antara santan cair, tepung ketan dan tepung beras. 
4. Melakukan pemasakan adonan pertama hingga kental. Suhu yang digunakan dalam pemasakan ini dianggap seragam untuk kedua metode pemasakan. Mencatat waktu yang digunakan selama pemasakan; $t_{1}$ merupakan waktu awal pemasakan dan $t_{2}$ merupakan waktu akhir pemasakan. $t_{1}$ adalah waktu dimulainya pengapian dan pengadukan adonan, sementara $t_{2}$ adalah waktu berakhir pemasakan adonan yang ditandai dengan adonan mengeluarkan minyak dan mengental.

5. Memasukkan adonan kedua ke dalam adonan pertama.

6. Melakukan pengadukan selama pemasakan dan mencatat waktu yang diperlukan selama pengadukan hingga dodol benar-benar matang. $\mathrm{t}_{1}$ pada tahap ini merupakan $\mathrm{t}_{2}$ pada pengadukan adonan pertama, sedangkan $t_{2}$ merupakan waktu akhir pemasakan dodol $\left(\mathrm{t}_{3}\right)$ yang ditandai dengan tekstur dodol yang kalis serta terlihat homogen.

7. Data-data tersebut selanjutnya dianalisis dan dibandingakan.

\section{HASIL DAN PEMBAHASAN}

Pada penelitian ini, dodol dibuat dengan dua metode pengadukan, yakni pengadukan secara manual dan otomatis. Berdasarkan dua metode ini akan dibandingkan lamanya pembuatan dodol serta hasil yang diperoleh. Setelah adonan pertama masak dan homogen, maka selanjutnya mencampurkan adonan kedua. Lamanya waktu pemasakan dodol dimulai dari pemanasan adonan pertama hingga dodol masak.

Hasil Pengamatan

Tabel 2. Komposisi Campuran

\begin{tabular}{|l|l|l|}
\hline No & Bahan & Kuantitas \\
\hline 1 & Tepung beras ketan & $1 \mathrm{~kg}$ \\
\hline 2 & Santan kental & $65 \mathrm{~mL}$ \\
\hline 3 & Santan cair & $5 \mathrm{~L}$ \\
\hline 4 & $\begin{array}{l}\text { Gula merah (gula } \\
\text { aren) }\end{array}$ & $2 \mathrm{~kg}$ \\
\hline 5 & Gula pasir & $0,25 \mathrm{~kg}$ \\
\hline
\end{tabular}

Tabel 3. Data Hasil Penelitian

\begin{tabular}{|l|c|c|c|c|l|}
\hline Sistem & \multicolumn{3}{|c|}{ Waktu } & $\begin{array}{l}\text { Wtotal } \\
\text { Pengadukan }\end{array}$ & $\begin{array}{l}\text { Hasil } \\
\text { Tekstur }\end{array}$ \\
\cline { 2 - 6 } $\begin{array}{l}\text { Tradisional/ } \\
\text { Manual }\end{array}$ & 13.30 & 13.44 & 15.39 & 139 & $\begin{array}{l}\text { Agak } \\
\text { Keras/ } \\
\text { Getas }\end{array}$ \\
\hline $\begin{array}{l}\text { Modern/ } \\
\text { Otomatis }\end{array}$ & 16.00 & 16.12 & 17.41 & 101 & Kenyal \\
\hline
\end{tabular}

Keterangan:

$\mathrm{t}_{1}=$ waktu saat pemanasan adonan pertama

$\mathrm{t}_{2}=$ waktu pemanasan adonan pertama selesai $=$ waktu saat adonan kedua ditambahkan ke adonan pertama

$\mathrm{t}_{3}=$ waktu dodol masak

Analisis Data dan Pembahasan

Hubungan Metode dengan Waktu

Pembuatan dodol dengan pengadukan secara manual memerlukan waktu yang cukup lama dibandingkan dengan pengadukan secara otomatis. Walaupun saat pemanasan adonan pertama (pencairan gula merah) terlihat memerlukan waktu yang tidak jauh berbeda. Perbedaan ini menghemat waktu sekitar 30 menit dalam pembuatannya untuk komposisi campuran yang sama. Artinya, pengadukan secara otomatis (menggunakan alat) berpengaruh pada cepatnya pemasakan. Beberapa penelitian lain juga menunjukkan adanya kecenderungan ini, yakni pembuatan dodol dengan pengadukan menggunakan mesin (otomatis) memiliki waktu yang lebih cepat dibandingkan pengadukan secara manual. Implementasi pengadukan dodol dengan teknologi mesin menghasilkan reduksi waktu tanak dodol 2 jam yaitu dari 4 jam secara manual menjadi 2 jam dengan teknologi mesin (Napid, dkk., 2014).

Pengurangan waktu yang diperlukan dalam pembuatan dodol menggunakan mesin dapat dijelaskan bahwa pengadukan dengan mesin memiliki putaran yang konstan sehingga akan lebih merata dibandingkan pengadukan manual yang bisa jadi dominan pada daerah tertentu. Akibatnya, untuk menghasilkan dodol yang benarbenar matang secara merata memerlukan waktu yang lebih lama. Pembuatan dodol dengan menggunakan mesin (Gambar 6) lebih higienis dan dapat meningkatkan produktifitasnya.

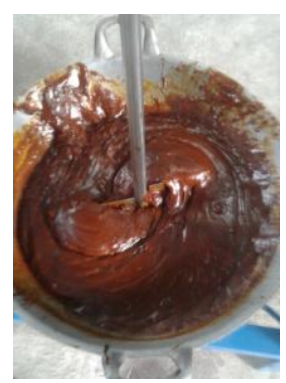

Gambar 6. Pengadukan Dodol

Dikatakan higienis karena saat pengadukan tanpa ada campur tangan manusia sehingga kemungkinan-kemungkinan yang dapat terjadi saat 
pengadukan secara manual dapat dihindari, seperti tercampurnya bahan dodol dengan keringat manusia atau tercampurnya dengan kotorankotoran lain karena tangan yang tidak bersih/steril.

Adapun waktu yang relatif lebih cepat dalam pembuatan dodol menggunakan mesin memungkinkan untuk meningkatkan produktivitasnya. Sebagai contoh, jika alokasi waktu dalam satu hari sebanyak 8 jam produktif maka dalam satu hari dapat memproduksi dodol dari bahan dasar sebanyak 4,8 kg, 1,3 kg lebih banyak jika dibandingkan pengadukan secara manual, yakni $3,5 \mathrm{~kg}$ dalam satu hari. Misalkan dodol dijual Rp 2000/bungkus ( 1 bungkus $=200$ gr) maka akan diperoleh omset sebesar Rp 48000, yakni Rp 13000 lebih besar dibandingkan menggunakan pengadukan secara manual. Dengan demikian, penggunaan mesin dalam pembuatan dodol dapat meningkatkan produktivitasnya.

\section{Hubungan Metode dengan Kualitas Dodol}

Penggunaan mesin pengaduk (pengadukan secara otomatis) dapat meningkatkan tekstur dodol yang dihasilkan. Hal ini karena dodol pada umumnya memiliki tekstur yang agak kenyal. Pada pengadukan secara manual, dodol yang dihasilkan agak getas. Artinya, ketika dodol ditarik akan segera putus tanpa mengalami cukup elongasi. Kondisi ini dapat dijelaskan bahwa pengadukan secara manual berpengaruh pada tidak meratanya sebaran pengadukan karena bisa jadi hanya terkonsentrasi pada titik tertentu, sehingga dodol tidak matang secara merata. Akibat lainnya adalah pengadukan secara manual tidak menghasilkan dodol yang matang secara sempurna sehingga diperlukan waktu yang cukup lama agar panas terdistribusi secara merata.

Hal ini tidak bisa diatasi dengan ditingkatkan panas apinya karena api yang terlalu besar juga berpengaruh pada dodol yang tidak matang secara sempurna, dibagian tertentu gosong tapi dibagian yang lain belum masak. Pengadukan menggunakan mesin memungkinkan terbentuknya pasta yang kental sehingga saat dodol didinginkan akan membentuk tekstur yang kenyal, lenting, dan liat.

Disamping tekstur, kualitas dodol juga dapat dilihat dari segi warna. Hal ini juga berkaitan dengan tekstur dodol yang dihasilkan. Dodol yang dihasilkan dari pengadukan menggunakan mesin memiliki warna yang lebih gelap (Gambar 7) dibandingan dodol yang dihasilkan dengan pengadukan secara manual (Gambar 8). Perbedaan warna ini menunjukkan bahwa warna gelap dodol merupakan indikator bahwa dodol telah matang secara sempurna dan memiliki tekstur yang kenyal.
Peristiwa ini juga dapat dikaitkan dengan proses karamelisasi, dimana proses ini merupakan reaksi pencokelatan non enzimatik. Karamel yang terbentuk selama proses pemanasan memberikan warna coklat pada produk pangan sehingga meningkatkan warna dodol (Nusa, dkk., 2012).

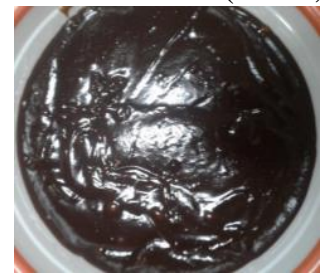

Gambar 7. Dodol hasil Pengadukan Menggunakan Mesin

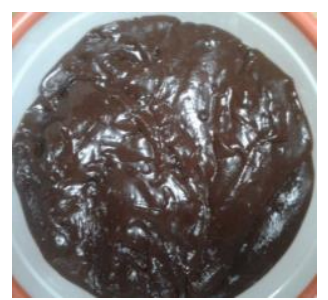

Gambar 8. Dodol yang Diaduk Secara Manual

Pengadukan menggunakan mesin mempercepat peningkatan konsentrasi campuran dodol sehingga rasa dan aroma yang dihasilkan semakin tinggi. Peningkatan konsentrasi campuran dodol mengakibatkan terbentuknya karamel yang membuat rasa dan aroma dodol lebih enak, lebih tajam sehingga rasa dan aroma dodol lebih disukai. Karamelisasi disebabkan oleh reaksi gula pereduksi dengan gugus amina primer atau pemakaian suhu tinggi pada sukrosa. Pencoklatan ini sengaja dibuat untuk menimbulkan bau dan cita rasa yang dikehendaki.

\section{KESIMPULAN DAN SARAN}

\section{Kesimpulan}

1. Pembuatan dodol menggunakan mesin pengaduk otomatis memerlukan waktu yang lebih cepat dibandingkan pengadukan secara manual. Pengadukan dodol menggunakan mesin memerlukan waktu 101 menit, sedangkan pengadukan secara manual memerlukan waktu selama 139 menit.

2. Pembuatan dodol menggunakan mesin pengaduk otomatis menghasilkan dodol yang kenyal dan berwarna lebih coklat, serta memiliki aroma dan cita rasa yang semakin tinggi. 


\section{Saran}

1. Perlu adanya penelitian lanjutan dengan memvariasikan putaran pengadukan dan jenis pengaduk yang digunakan.

2. Juga dengan memvariasikan komposisi bahan campuran atau dengan tambahan bahan-bahan yang lain untuk meningkatkan kualitas dodol yang dihasilkan.

\section{DAFTAR PUSTAKA}

Anonym, 2013, Dodol Betawi Usaha Warisan Keluarga Penganan Khas Lebaran, https://gunrakyatbekasi.wordpress.com/2013/08/15/ dodol-betawi-usaha-warisan-keluarga-penganankhas-lebaran/

Fatma, M.A., 2015, Eksperimen Pembuatan Dodol Labu Kuning, Skripsi, Jurusan Pendidikan Kesejahteraan Keluarga, Fakultas Teknik, Universitas Negeri Semarang, Semarang.

Haryadi., Sai'in., dan Suhardi., 1998, Modifikasi Proses Pembuatan Dodol, Agritech, vol. 18, No. 1, hal. 2933.

Heroito, G., 2018, Perbaikan Mesin Pengaduk Dodol, Tugas Akhir, Jurusan Teknik Mesin Fakultas Teknologi Industri Universitas Islam Indonesia, Yogyakarta.
Krisnakai., 2017, Pengertian Makanan Dodol. https://bukuteori.com/2017/11/05/pengertianmakanan-dodol/

Napid, S., Haris Nst, A., Yusmartato, dan Abdurrozzaq Hsb., 2014, IbM Kelompok Usaha Dodol di Desa Bengkel Kabupaten Serdang Bedagai, Wahana Inovasi, Vol. 3, No. 1, hal. 94-103.

Nusa, M.I., Fuadi, M., dan Pulungan, W.A.P., 2012, Studi Pembuatan Dodol Pisang, Agrium, Vol. 17, No. 3, hal. 227-235.

Riandadari, D., 2017, Modifikasi Mesin Pengaduk Dodol dan Jenang Tipe Vertikal, JRM, vol. 04, No. 02, hal. 47-51.

Rumah Mesin, 2018, Mesin Pengaduk Dodol - Mesin Dodol Terbaru 2018, https://www.rumahmesin.com/produk/mesinpengaduk-dodol-aneka-bahan/

SNI, 1992, Dodol, SNI 01-2986-1992. Badan Standar Nasional: Jakarta.

Soemaatmadja, 1997, Pengawetan Pangan di Indonesia, IPB, Bogor. 